\title{
Thermal sensitivity of cellular energy budgets in some Antarctic fish hepatocytes
}

Received: 22 October 2004/ Revised: 29 April 2005/ Accepted: 2 May 2005/Published online: 26 July 2005

(C) Springer-Verlag 2005

\begin{abstract}
Oxygen demand elicited by the main cellular energy consumers was examined in isolated hepatocytes of sub-Antarctic (Lepidonotothen larseni) and highAntarctic notothenioids (Trematomus eulepidotus, Trematomus pennellii, Trematomus lepidorhinus, Trematomus bernacchii, Artedidraco orianae) and in a zoarcid (Pachycara brachycephalum) fish with respect to the role of cellular metabolism in co-defining thermal tolerance. The relative proportions of energy allocated to protein and RNA/DNA synthesis, ion regulation and ATP synthesis were quantified between $0^{\circ} \mathrm{C}$ and $15^{\circ} \mathrm{C}$ by analysis of inhibitor sensitive cellular respiration. In all the investigated species, protein synthesis constituted $25-37 \%$, RNA synthesis $24-35 \%, \mathrm{Na}^{+} / \mathrm{K}^{+}$-ATPase $40-45 \%$ and mitochondrial ATP synthesis $57-65 \%$ of total respiration. The sub-Antarctic nototheniid L. larseni displayed lower cellular protein synthesis rates but somewhat higher active ion regulation activities than its high-Antarctic confamilials, as is typical for more eurythermal species. Assumed thermal optima were mirrored in minimized overall cellular energy demand. In the sub-Antarctic L. larseni and P. brachycephalum, minima of oxygen consumption were located between $3^{\circ} \mathrm{C}$ and $6^{\circ} \mathrm{C}$, indicating elevated energy turnover below and above these temperatures. In contrast, the highAntarctic species displayed progressively rising respiration rates during warming with a cellular energetic minimum at $0^{\circ} \mathrm{C}$. The sub-Antarctic nototheniid and the zoarcid showed signs of cold-eurythermy and appear to live close to their lower limit of thermal tolerance, while high-Antarctic notothenioids show high degrees of energetic efficiency at $0^{\circ} \mathrm{C}$. All cellular preparations maintained energy budgets over a wide thermal range, supporting the recent concept that thermal limits are set
\end{abstract}

F. C. Mark $(\bowtie) \cdot$ T. Hirse · H. O. Pörtner

Alfred-Wegener-Institut für Polar- und Meeresforschung,

Physiologie mariner Tiere, Postfach 1201 61,

27515 Bremerhaven, Germany

E-mail: fmark@awi-bremerhaven.de

Tel.: + 49-471-48311015

Fax: + 49-471-48311149 by oxygen and associated energy limitations at the whole organism level.

\section{Introduction}

Fish of the perciform suborder Notothenioidei comprise most of the fish species living in the Southern Ocean (Gon and Heemstra 1990). They began to radiate into Antarctic waters in the early Tertiary, gradually adapting to the progressive cooling, which set in after the opening of the Drake passage and the formation of the circumpolar current some 25 million years ago (Eastman 1993; Arntz et al. 1994). The further South into high-Antarctic waters some of these species radiated, the more they became specialized to the permanent cold through unique adaptations at molecular, cellular and systemic levels (Kock 1992; Detrich 1997; Pörtner et al. 2005). Eventually, this even led to the loss of respiratory proteins in the white blooded Channichthyidae (Di Prisco 2000). The downside of this high degree of coldspecialisation was the development of cold-stenothermy, mirrored by increased mitochondrial densities at uncompensated capacities (Johnston et al. 1998; D'Amico et al. 2002; Lucassen et al. 2003) combined with reductions in hematocrit (Egginton 1997b) and cardiovascular output (Egginton 1997a). Specialisation has thus forced some of these species to lead a less active, rather sluggish lifestyle. Extreme stenothermy also made them very susceptible to stress induced by warming, with upper thermal limits around $6^{\circ} \mathrm{C}$ in Trematomus bernacchii, T. hansoni and P. borchgrevinki (Somero and DeVries 1967).

The first line of thermal limitation in animals is mirrored in the onset of functional hypoxia at the organismic level, followed by a hierarchical sequence of systemic to molecular stress events (Pörtner 2002). Some of these principles have also been confirmed in Antarctic 
fish. For example, oxygen demand in increasing hyperthermia soon exceeds the capacity of oxygen supply and finally drives the animal into anaerobic metabolism (e.g. Van Dijk et al. 1999). Findings obtained in a recent study of Antarctic eelpouts (Mark et al. 2002) were in line with the suggested hierarchy in the processes defining thermal limits and elaborated a key role of the circulatory system in setting thermal tolerance, firstly by ensuring oxygen supply, secondly by contributing to oxygen demand through enhanced circulatory work at high temperatures. Oxygen demand is also generated at the cellular level. However, the potential changes in cellular processes and their oxygen demand upon cooling or warming and the resulting contributions of the various cellular processes to whole animal thermal intolerance have not yet been addressed.

Therefore, the present study sets out to investigate the potential role of cellular processes in thermal limitation. As cells exposed to suboptimal conditions may face a shift in the distribution of metabolic resources, analysis of the energy available to various processes of cellular maintenance and proliferation may provide a sensitive measure of environmental and/or thermal stress. Atkinson (1977) suggested that there is a hierarchy in ATP-consuming processes, which in accordance with their functional importance show different sensitivities towards a reduction of the cellular energy load. This study aims to investigate temperature dependent energy allocation to the most important metabolic processes in hepatocytes of the highly thermally sensitive notothenioids, which are protein synthesis, RNA/DNA synthesis, ion regulation $\left(\mathrm{Na}^{+} / \mathrm{K}^{+}\right.$-ATPase), and ATP synthesis. Data were examined with respect to preferences in cellular energy allocation and the potential existence of threshold temperatures that might contribute to thermal tolerance limits of the whole organism.

\section{Materials and methods}

\section{Animals}

All fish used for the analysis of the energy budgets belonged to the perciform suborder of Notothenioidei and were caught in bottom trawls and semi-pelagic trawls between November 2003 and January 2004 on cruise ANT XXI/2 of the German research vessel Polarstern. Fish of the sub-Antarctic nototheniid species Lepidonotothen larseni $(17.1 \pm 2.0 \mathrm{~cm} ; 34.3 \pm 13.5 \mathrm{~g} ; n=29)$ were collected off Bouvet Island (54³0.22 S; $003^{\circ} 14.37$ E). The high-Antarctic notothenioid Artedidraco orianae (Artedidraconidae; $14.8 \pm 1.3 \mathrm{~cm} ; 30.0 \pm 6.5 \mathrm{~g} ; n=5$ ), and the trematomid nototheniids Trematomus lepidorhinus $(15.1 \pm 4.8 \mathrm{~cm} ; 45.6 \pm 31.8 \mathrm{~g} ; n=8)$, T. eulepidotus $(21.1 \pm 2.7 \mathrm{~cm} ; \quad 100.0 \pm 50.9 \mathrm{~g} ; n=7), \quad T$. pennellii $(21.7 \pm 3.2 \mathrm{~cm} ; 143.1 \pm 62.3 \mathrm{~g} ; n=17)$ and $T$. bernacchii $(23.3 \mathrm{~cm} ; 131.0 \mathrm{~g} ; n=1)$ were collected in the eastern Weddell Sea. Until experimentation, fish were maintained onboard the vessel in an air-conditioned container equipped with aquaria and aerated recirculated natural seawater at $0.5 \pm 1.0^{\circ} \mathrm{C}$ for $2-3$ weeks. Fish that did not demonstrate good health over this period were not used in the experiments. Fish were not fed for several days prior to the experiments, which were all carried out in the laboratories onboard.

A second suite of experiments to record cellular respiration rates of hepatocytes of the Antarctic eelpout Pachycara brachycephalum $(22.9 \pm 1.3 \mathrm{~cm} ; 51.1 \pm 8.4 \mathrm{~g}$; $n=11)$ was conducted in the thermal range of $0-21^{\circ} \mathrm{C}$. These experiments were carried out at the Alfred Wegener Institute between December 2001 and March 2002. Fish used in these experiments were caught at a depth of $500 \mathrm{~m}$ close to King George Island (Antarctic Peninsula) during the cruise ANT XIX of Polarstern in April/May 2001. Fish were transferred to the institute and kept in well-aerated water at $0.0 \pm 0.5^{\circ} \mathrm{C}$ and 32 $34 \%$ salinity until experimentation. They were fed live shrimps ad libitum once per week and starved 1 week before experimentation.

\section{Preparation of cellular isolates}

Hepatocytes were isolated following a protocol modified after Mommsen et al. (1994). Fish were anaesthetised in MS-222 (3-Amino-benzoic-methanosulfonate, $0.5 \mathrm{~g} \mathrm{l}^{-1}$ ); the liver was carefully excised and transferred into a Petri dish on ice with $4 \mathrm{ml} \mathrm{g}^{-1}$ fresh weight of solution 1 (Hank's Medium without magnesium (to prevent blood clotting), containing: glucose: $5.6 \mathrm{mM}$; $\mathrm{KCl}: 5 \mathrm{mM}$; $\mathrm{NaHCO}_{3}: 4 \mathrm{mM} ; \mathrm{Na}_{2} \mathrm{HPO}_{4}: 0.3 \mathrm{mM}$; NaCl: $240 \mathrm{mM}$; $\mathrm{KH}_{2} \mathrm{PO}_{4}$ : $0.4 \mathrm{mM}$; HEPES: $10 \mathrm{mM}$; $\mathrm{pH}$ 7.4). Fish were killed afterwards by a cut through the spine and removal of the heart. Blood was removed from the liver by perfusion of the Vena hepatica with ice-cold solution 1, until no more blood cells were visible in the drain. Then, the liver was perfused on ice via the Vena hepatica with $2 \mathrm{ml} \mathrm{g}^{-1}$ fresh weight ice-cold collagenase solution (solution 3: solution $1+1 \% \mathrm{BSA}+750 \mathrm{U} \mathrm{ml}^{-1}$ collagenase type IV) and gently massaged for about $10 \mathrm{~min}$. Peritoneal tissue was removed, the rest finely chopped and gently shaken on ice for about 60 minutes, until total disintegration of the tissue. The solution was then filtered through a $250 \mu \mathrm{m}$ mesh-size gaze. Hepatocytes were collected by gentle centrifugation $(4 \mathrm{~min}$ at $60 \mathrm{~g}$ ) and washed repeatedly by centrifugation $(2 \mathrm{~min}$ at $60 \mathrm{~g})$ in solution 2 (solution $1+1 \%$ BSA), until the lipid phase and all erythrocytes were removed. Cells were stored in solution 4 (solution $2+5 \mathrm{mM}$ glucose and $2 \mathrm{mM}$ $\left.\mathrm{MgSO}_{4}\right)$ at $0^{\circ} \mathrm{C}$ on a shaking desk. Cell titres were assessed in a Fuchs-Rosenthal haemocytometer dish and viability of cells was determined by Trypan blue exclusion $(>95 \%)$. Total protein content was measured according to Bradford (1976). Samples of cellular suspensions were frozen in liquid nitrogen, stored at $-80^{\circ} \mathrm{C}$ and broken up by ultrasound treatment before analysis $\left(4 \mathrm{~min}\right.$ at $\left.0^{\circ} \mathrm{C}\right)$. All chemicals and media were obtained from Sigma-Aldrich, Germany. 
Respiration and inhibitors

Cells from about $5 \mathrm{~g}$ to $10 \mathrm{~g}$ liver tissue were freshly isolated each day. When necessary, several animals of the smaller species were pooled to collect enough liver fresh mass. Cellular suspensions were diluted to $15 \times 10^{6}$ cells $\mathrm{ml}^{-1}$ and kept under constant shaking on ice in solution 4 throughout the experiments. Measurements were carried out in duplicates in two parallel setups consisting of Perspex respiration chambers (Ranks Brothers, Cambridge, UK) that could be volume adjusted between $300 \mu \mathrm{l}$ and $1,500 \mu \mathrm{l}$ and temperature controlled by a thermostat (Lauda, Königshofen, Germany). Respiration was measured using micro-optodes and the TX system of PreSens (PreSens GmbH, Regensburg, Germany), connected to a laptop computer (Compaq Armada 500) via a MacLab system running the Chart 5.0 software (ADInstruments, Caste Hill, Australia).

An amount of $300 \mu \mathrm{l}$ of the cell suspension were spun down briefly $\left(1 \mathrm{~min}, 60 \mathrm{~g}, 0^{\circ} \mathrm{C}\right)$ and $200 \mu \mathrm{l}$ of the supernatant exchanged with fresh ice-cold solution 4. The cells were then resuspended and transferred into the respiration chambers. The chambers were sealed airtight and a micro-optode was inserted through the lid. Blank respiration was recorded for $20 \mathrm{~min}$, then the optode was withdrawn and inhibitor stock solution was added to the suspension with a microlitre glass syringe (Hamilton, Bonaduz, Switzerland). After reintroduction of the micro-optode, respiration was recorded for $40 \mathrm{~min}$. The cells were removed and respiration chambers washed twice with distilled water and $70 \%$ ethanol. A new experiment was run with fresh cells and a different inhibitor. Respiration rates were calculated and cellular respiration in the presence of an inhibitor was quantified in relation to its respective control rate to account for potential deterioration of cell quality over time. Cell viability was checked after the last run and was always found to be $>90 \%$.

The following inhibitors were used:

Cycloheximide was used at a concentration of $100 \mu \mathrm{M}$ to inactivate peptidyl transferase activity of the ribosomal $60 \mathrm{~S}$ subunit [i.e. to inhibit protein synthesis, Wieser and Krumschnabel 2001; Langenbuch and Pörtner 2003]. To estimate the energetic needs of $\mathrm{Na}^{+} /$ $\mathrm{K}^{+}$-ATPase, ouabain was used at a concentration of 6.67 mM (Pannevis and Houlihan 1992; Krumschnabel et al. 1994a). Actinomycin D was administered at a concentration of $100 \mathrm{nM}$ to block RNA and DNA synthesis (Smith and Houlihan 1995). To inhibit mitochondrial ATP production $\left(\mathrm{F}_{0} \mathrm{~F}_{1}\right.$-ATPase $)$, cells were incubated with $10 \mu \mathrm{g} \mathrm{ml}^{-1}$ oligomycin (Gamper and Savina 2000).

All inhibitors were dissolved in DMSO, preliminary experiments had shown that DMSO addition of $<5 \%$ of the total assay volume did not affect respiration rates. In a preliminary set of experiments, we determined the minimum concentrations of inhibitors sufficient for maximum reduction of oxygen consumption, since it has been shown that overdoses of inhibitors can lead to overestimates of the particular metabolic process due to side effects and even to cell death (Wieser and Krumschnabel 2001). Due to possible cross reactivity, inhibitors were never applied in combination.

\section{Statistical analysis}

Statistical analyses of differences between total cellular respiration rates and differences between inhibited fractions of total respiration were carried out using Prism 4.0a and InStat 3.0b (GraphPad Software, Inc.). Differences between control and elevated respiration rates in the warm were determined by t-tests and considered significant if $P<0.05$.

To test for the temperature sensitivity of each cellular process identified by its specific inhibitor, data were arcsin transformed and analysed through Spearman Rank correlations and one-way analyses of variance (ANOVA). Furthermore, differences between inhibitor sensitive respiration at control and elevated temperatures were additionally determined by t-tests, which were also applied to test for differences of the total means (within the thermal range of $0-15^{\circ} \mathrm{C}$ ) of inhibitor sensitive respiration between investigated species.

Again, differences were considered significant if $P<0.05$. If not stated otherwise, all data are presented as values \pm standard error of the mean (SEM).

\section{Results}

\section{Respiration}

Oxygen consumption rates of isolated hepatocytes between $0^{\circ} \mathrm{C}$ and $15^{\circ} \mathrm{C}$ were between $0.1 \mathrm{nmol}$ and $0.7 \mathrm{nmol} \mathrm{O}_{2} \times 10^{6}$ cells $^{-1} \mathrm{~min}^{-1}$ in all examined species (Figs. 1, 2). In contrast to the high-Antarctic species, the sub-Antarctic notothenioid L. larseni showed the lowest rates of cellular oxygen consumption between $3^{\circ} \mathrm{C}$ and $6^{\circ} \mathrm{C}$ (Fig. 1a). The Antarctic zoarcid, P. brachycephalum displayed a similar pattern, lowest rates of oxygen consumption were around $3^{\circ} \mathrm{C}$ and rose upon warming as well as cooling (Fig. 2). These species were the only ones to show an increase in oxygen consumption upon cooling from $3^{\circ} \mathrm{C}$ to $0^{\circ} \mathrm{C}$. In the high-Antarctic notothenioids (Fig. $1 \mathrm{~b}-\mathrm{e}$ ), lowest rates were found at $0^{\circ} \mathrm{C}$, cellular rates of oxygen consumption were significantly higher at all temperatures greater than $0^{\circ} \mathrm{C}$. The increases in oxygen consumption followed variable patterns in each species: in T. eulepidotus hepatocytes (Fig. 1b) there was a steady increase in respiration rates with temperature with a tendency to level off between $12^{\circ} \mathrm{C}$ and $15^{\circ} \mathrm{C}$. Cells obtained from $T$. pennellii showed a more moderate increase up to $9^{\circ} \mathrm{C}$, followed by a steep increment to the highest rates of oxygen consumption observed in the investigated species (Fig. 1c). Oxygen demand of T. lepidorhinus hepatocytes rose during warming to $6^{\circ} \mathrm{C}$ 

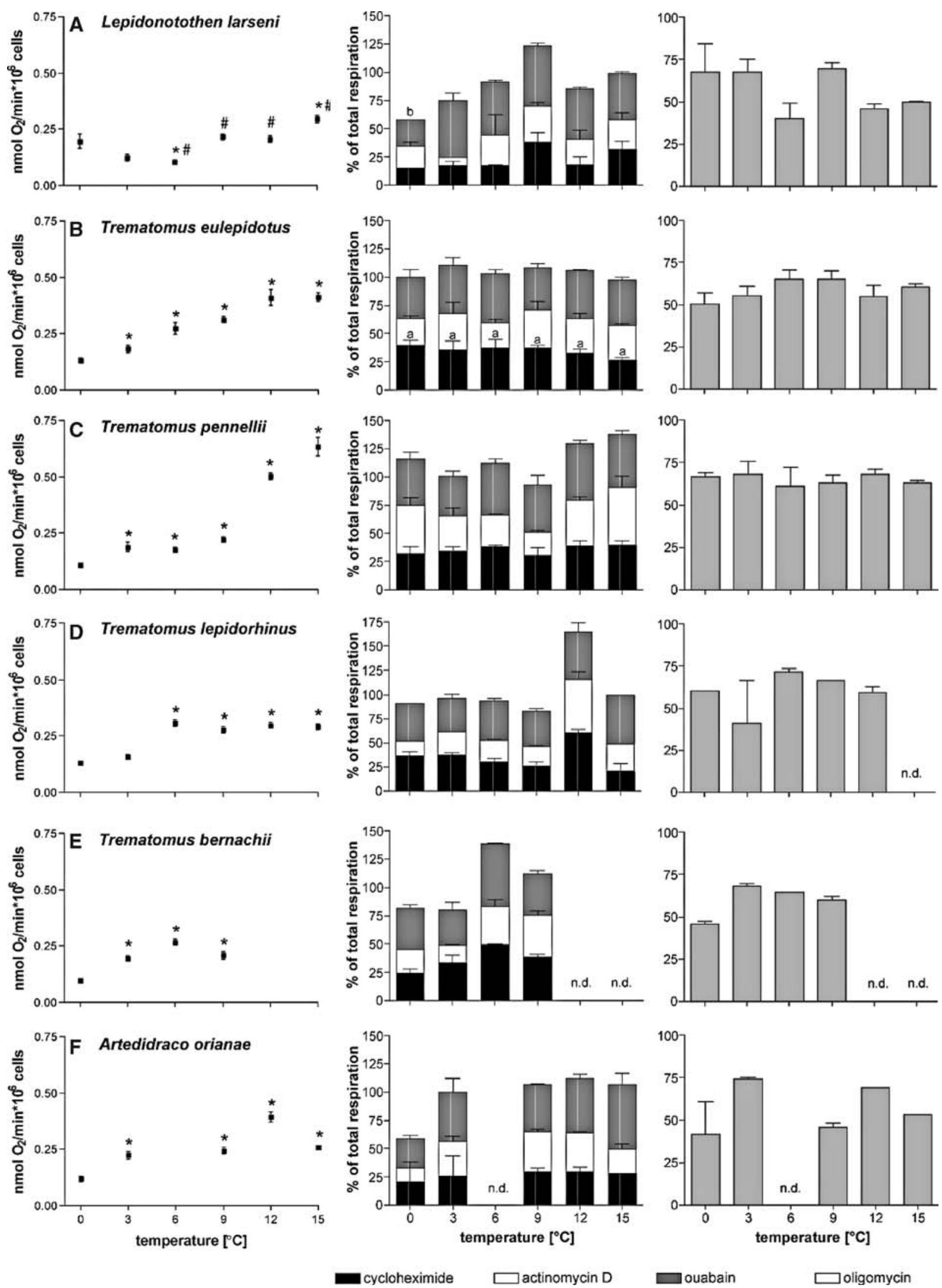

(Fig. 1d) and remained constant thereafter. In T. bernacchii cellular respiration also rose and levelled off beyond $6^{\circ} \mathrm{C}$ (Fig. 1e), while in A. orianae hepatocytes

oxygen consumption peaked at $12^{\circ} \mathrm{C}$ (Fig. 1f). Yet, in these two species the picture is incomplete due to insufficient availability of tissue samples. 
Fig. 1 From left to right: Cellular respiration (left) and energy budgets (middle and right) in the temperature range between $0^{\circ} \mathrm{C}$ and $15^{\circ} \mathrm{C}$. The investigated species $(\mathbf{a}-\mathbf{f})$ are listed from top to bottom. In the energy budgets, inhibitor sensitive respiration is depicted as follows: black: cycloheximide sensitive respiration (protein synthesis); white: actinomycin D sensitive respiration (RNA/DNA synthesis); dark grey: ouabain sensitive respiration $\left(\mathrm{Na}^{+} / \mathrm{K}^{+}\right.$-ATPase); and light grey: oligomycin sensitive respiration $\left(\mathrm{F}_{0} \mathrm{~F}_{1}\right.$-ATPase). Asteriks indicate cellular respiration rates significantly different from values at $0^{\circ} \mathrm{C}(P<0.05)$, \# indicates cellular respiration rates significantly different from values at $3^{\circ} \mathrm{C}$ $(P<0.05)$. a: significant decrease in oligomycin sensitive respiration from $0^{\circ} \mathrm{C}$ to $15^{\circ} \mathrm{C}$ (T. eulepidotus); $b$ : ouabain sensitive respiration significantly lower than at $6-15^{\circ} \mathrm{C}$ (L. larseni); n.d.: not determined; $n=1-8$ per data point, all values given as means \pm standard error of the mean $(S E M)$, where applicable

\section{Energy budgets}

Within the cellular energy budgets, the largest oxygen consumers of the cell (RNA, protein and ATP synthesis, ion regulation) more or less uniformly claimed the same fraction of available oxygen over the entire investigated temperature range (Fig. 1). In all investigated species, mean cycloheximide sensitive respiration constituted 25-37\%, mean actinomycin sensitive respiration 24 $35 \%$, mean ouabain sensitive respiration $40-45 \%$ and mean oligomycin sensitive respiration accounted for $57-$ $65 \%$ (cf. Table 1). By measuring the oligomycin sensitive fraction of total respiration, ATP-synthesis was accounted for. Oligomycin sensitive respiration is a cue for mitochondrial efficiency and degree of coupling, measured by the $\mathrm{P} / \mathrm{O}$ ratio (moles of ATP produced per moles of $\mathrm{O}_{2}$ consumed). Subtracting oligomycin sensitive respiration from total respiration yields an indirect measure of processes like proton leak and non-mitochondrial respiration, which on average accounted for $35-43 \%$ in the hepatocytes of the species investigated here.

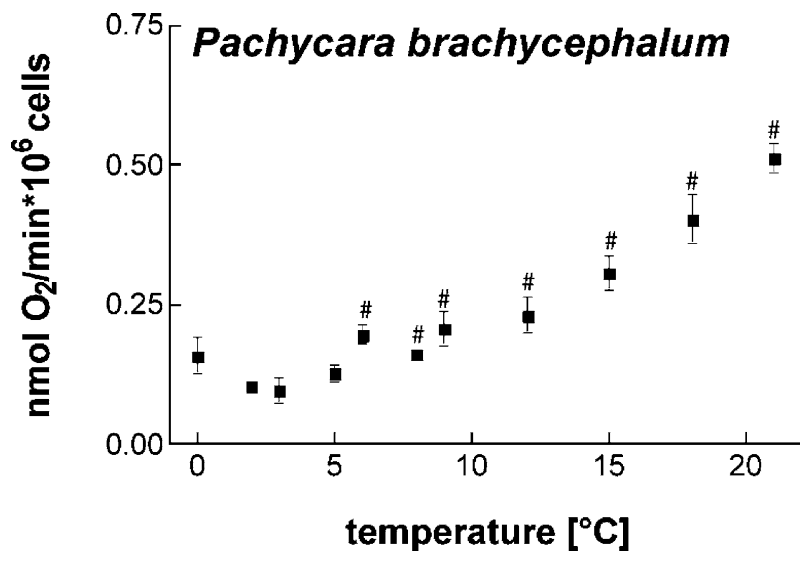

Fig. 2 Cellular respiration of hepatocytes of the Antarctic eelpout Pachycara brachycephalum in the thermal range between $0^{\circ} \mathrm{C}$ and $21{ }^{\circ} \mathrm{C} ; n=3-6$ per data point; all values given as means \pm standard error of the mean $(S E M)$. \# indicates cellular respiration rates significantly different from values at $3^{\circ} \mathrm{C}(P<0.05)$

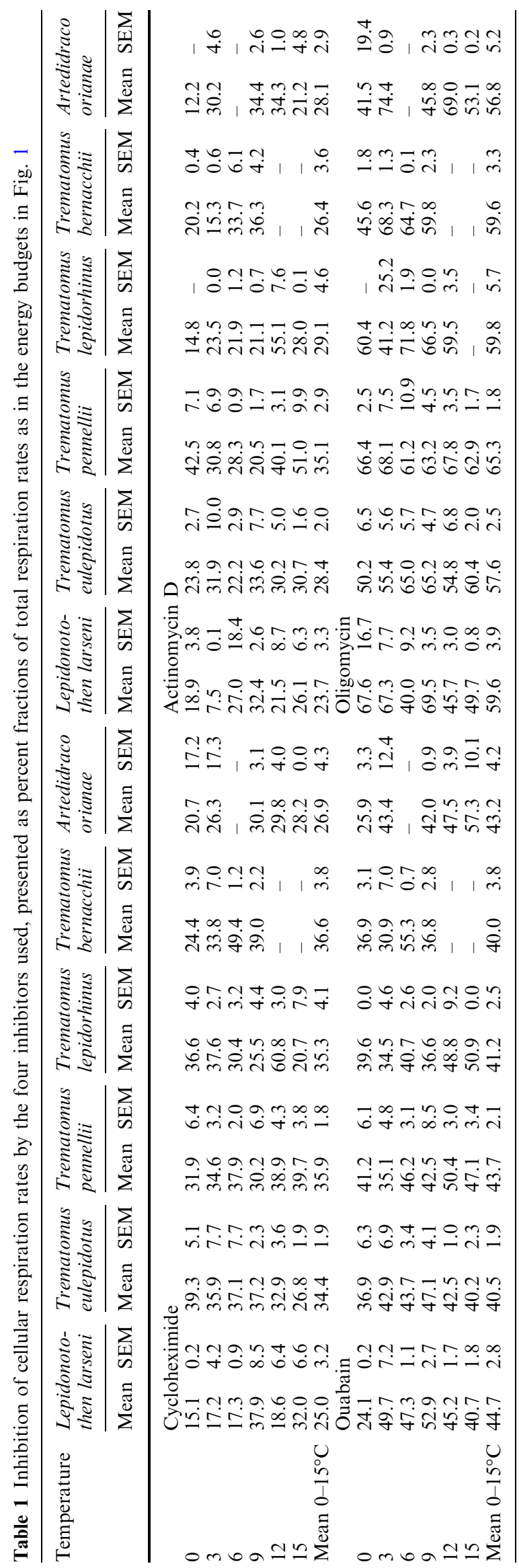


In Trematomus eulepidotus, we found a significant decrease in cycloheximide sensitive respiration with increasing temperature (Fig. 1b).

In parallel to an increase in cellular respiration between $3^{\circ} \mathrm{C}$ and $0^{\circ} \mathrm{C}$, the energy budget of the sub-Antarctic species Lepidonotothen larseni (Fig. 1a) displayed significant reductions in cycloheximide and ouabain sensitive respiration while oligomycin sensitive respiration was slightly elevated $(67 \%$, cf. Table 1$)$, and actinomycin D sensitive respiration appeared suppressed at $3^{\circ} \mathrm{C}$.

\section{Discussion}

The aim of this study was to elaborate temperature dependent energy allocation to key metabolic processes in the cell. It was based on the question whether warm temperatures would elicit disturbances in cellular energy allocation that might contribute to whole organism thermal intolerance, especially so in the thermally most sensitive high-Antarctic notothenioids.

\section{Cellular respiration}

Hepatocyte oxygen consumption was very similar in all investigated species, ranging from $0.1 \mathrm{nmol} \mathrm{O}_{2} \times$ $\min ^{-1} 10^{6}$ cells $^{-1}$ at low temperatures to a maximum of about $0.7 \mathrm{nmol} \mathrm{O}_{2} \times \mathrm{min}^{-1} 10^{6}$ cells $^{-1}$ in $T$. pennellii at $15^{\circ} \mathrm{C}$ (Figs. 1, 2). This is in line with respiration data recorded in hepatocytes from a variety of fish species, Antarctic Lepidonotothen kempi (Langenbuch and Pörtner 2003); goldfish (Krumschnabel et al. 1994b); temperate zoarcids, Z. viviparus (F. Mark, unpubl. data). Moreover, hepatocytes of goldfish and trout measured at $20^{\circ} \mathrm{C}$ and $15^{\circ} \mathrm{C}$, respectively, show respiration rates $(0.4$ and $0.6 \mathrm{nmol} \mathrm{O}_{2} \times \mathrm{min}^{-1} 10^{6} \mathrm{cells}^{-1}$, respectively, Krumschnabel et al. 2001) similar to those of the high Antarctic trematomids at $15^{\circ} \mathrm{C}$. At the cellular level this observation confirms the absence of metabolic cold adaptation in these notothenioid species, as has been argued by Clarke and Johnston (1999) based on a literature survey of oxygen consumption data from whole animals.

Within the range of experimental temperatures, it becomes evident that cellular respiration does not necessarily increase upon warming. Metabolic processes are not always exponentially linked to temperature, $Q_{10}$ may fluctuate and can adopt higher values towards temperature extremes (Haschemeyer and Mathews 1982), and warming may then result in critically elevated respiration rates. Within the cellular oxygen consumption data presented in this study, we found clear evidence of speciesspecific patterns of cellular respiration, which will likely influence whole organism thermal sensitivity. Hepatocytes of the sub-Antarctic species L. larseni appeared to have the lowest energetic requirements between $3^{\circ} \mathrm{C}$ and $6^{\circ} \mathrm{C}$, below and above which cellular oxygen consumption rose. This indicates a rise in metabolic energy turnover in the liver in the cold, pointing to an energetic optimum (i.e. a temperature range of minimal energetic costs) for the organism at temperatures significantly higher than $0^{\circ} \mathrm{C}$ (Fig. 1a). In fact, specimens of L. larseni were caught off Bouvet Island $\left(54^{\circ} 30.22 \mathrm{~S}\right.$; $\left.003^{\circ} 14.37 \mathrm{E}\right)$, which is located within the oscillations of the Southern boundary of the Antarctic Polar front. Thus, water temperatures are influenced by both the cold waters of the Southern Ocean and the warmer waters of the South Atlantic and are bound to vary both annually and seasonally. Water temperatures at the time of the catch ranged around $0.6^{\circ} \mathrm{C}$. This relatively warm temperature contrasts values of -1.0 to $-1.8^{\circ} \mathrm{C}$ found in the Weddell Sea, where the high-Antarctic notothenioids were caught.

Observations of an energetic optimum are corroborated by the cellular oxygen consumption data recorded for the Antarctic eelpout Pachycara brachycephalum (Fig. 2), which showed a similar pattern with lowest oxygen consumption at $3^{\circ} \mathrm{C}$. This species is frequently found in sub-Antarctic conditions around the Antarctic peninsula, yet in the high Antarctic, P. brachycephalum only occurs in warmer Antarctic deep-water layers at temperatures above $0^{\circ} \mathrm{C}$ (R. Knust, AWI, personal communication). Accordingly, the eelpout as well as L. larseni probably live close to their lower ecophysiological limits in warmer, sub- or deep Antarctic waters. Consequently, they may be more cold eurythermal than the high-Antarctic cold stenotherms.

Different patterns of thermal responses could also be observed within the five remaining high-Antarctic notothenioid species of Trematomus and Artedidraco (Fig. 1b-f): in T. eulepidotus there was a steady increase in cellular respiration with temperature with a tendency to level off between $12^{\circ} \mathrm{C}$ and $15^{\circ} \mathrm{C}$, possibly indicating the onset of a limitation of hepatic metabolic capacity just above $12^{\circ} \mathrm{C}$. In contrast, hepatocytes of $T$. pennellii showed a dramatic twofold to threefold increase in respiration rate towards the warm end of the investigated thermal range. This drastic increment reflects an overproportional rise in metabolic costs, which is still covered by the capacity of cellular energy production, indicated by unchanged energy budgets. T. lepidorhinus neither showed a steady rise in cellular oxygen consumption, nor an abrupt increment. In the light of unchanged energy budgets, this species may be the least thermally sensitive among the investigated notothenioids. For T. bernacchii and $A$. orianae, data are insufficient but indicate limited metabolic capacities at higher temperatures (Fig. 1e, f). These patterns may reflect different and specific thermal sensitivities of the different species and calls for the respective investigations at the whole animal level.

\section{Cellular energy budgets}

\section{Methodological considerations}

Interpretation of inhibitor data is often problematic and error prone and therefore any such energy budget will 
have to be interpreted with adequate precaution. The choice of the medium used to measure cellular respiration is of eminent importance as is the concentration of the inhibitor. This has convincingly been shown in the work of Wieser and Krumschnabel (2001), who demonstrated for trout and goldfish hepatocytes, that cellular respiration increased up to five-fold and the relative fraction of protein synthesis rose considerably in free amino acid enriched Leibovitz (L-15) medium as compared to Hank's balanced salt solution. The authors also provided evidence for cycloheximide to inhibit far more metabolic processes than just protein synthesis when applied in overly high concentrations. Generally, by directly or indirectly affecting further metabolic processes, inhibitors will always act somewhat unspecific and the actual share of a particular metabolic process is overestimated. For example, we treated RNA/DNA synthesis and protein synthesis as discrete processes, which they are not: once mRNA synthesis is inhibited, protein synthesis will also decrease to some extent, due to a lack of new transcripts. Moreover, we did not account for $\mathrm{Ca}^{2+}$-ATPase or proton leak, the first of which comprises up to $10 \%$ of total cellular respiration in rat thymocytes (Buttgereit and Brand 1995) and the latter about $10 \%$ of maximum mitochondrial respiration in isolated liver mitochondria of the notothenioid Lepidonotothen nudifrons (Hardewig et al. 1999), respectively.

Still, cycloheximide, actinomycin D and ouabain sensitive respiration can add up to more than $100 \%$ of total cellular respiration, which is indicative of secondary inhibition of dependent processes. As a consequence, cellular energy budgets compiled by the use of inhibitors cannot claim to represent absolute contributions of the examined metabolic processes, but can provide an idea of the fraction of energy allocated to a specific process and how energy allocation may change qualitatively with a change in experimental conditions like temperature.

Bearing all this in mind and following a strict protocol, it is still possible to analyse thermally induced changes in the inhibitor sensitive fractions of total cellular respiration and gain valuable insights into potential shifts in cellular energy metabolism. In fact, the overall stability of the energy budgets regardless of temperature and despite large changes in cellular oxygen consumption provides indirect support for the validity of our measurements and the data analyses carried out.

\section{Variability in energy budgets}

Mean values of the data collected for the four inhibitors (cf. table 1) were in line with inhibitor sensitive fractions of respiration observed in fish cells by other authors: in the six species examined, the mean cycloheximide sensitive respiration was $25-37 \%$ (Krumschnabel et al. 1994a; Krumschnabel et al. 1997; Smith et al. 2001; Wieser and Krumschnabel 2001; Langenbuch and Pörtner 2003), mean actinomycin D sensitive respiration was 24-35\% (rat cells: Buttgereit and Brand 1995; fish cells: Smith and Houlihan 1995; Casey et al. 2002), mean ouabain sensitive respiration was 40-45\% (Krumschnabel et al. 1994a; Krumschnabel et al. 1994b; Krumschnabel et al. 2001), and mean oligomycin sensitive respiration was 57-64\% (Gamper and Savina 2000).

The temperature dependent variability patterns observed in cellular respiration did not largely affect energy budget components, suggesting that energy budgets remained rather stable and temperature insensitive.

In the sub-Antarctic species L. larseni, cycloheximide sensitive respiration appeared overproportionally reduced below $6^{\circ} \mathrm{C}$, indicating lower levels of protein synthesis in the cold in this species. At $3^{\circ} \mathrm{C}$ actinomycin D sensitive respiration appeared largely reduced compared to higher and lower temperatures, which may have consequences for RNA/DNA synthesis. The fraction of ouabain sensitive respiration was significantly reduced at $0^{\circ} \mathrm{C}$ when compared to $6^{\circ} \mathrm{C}$ and higher, a finding which indicates a potential shift in ion regulation processes. Alternatively, an unexplained ATP consuming process possibly rose in the cold and caused the respective reduction in the share of protein and RNA synthesis or ion exchange in the energy budget.

According to the theory of a hierarchy of ATP-utilizing processes first brought forward by Atkinson (1977) and corroborated by Buttgereit and Brand (1995) and Wieser and Krumschnabel (2001), protein synthesis is the process most sensitive to a change in ATP supply and will decrease first when a cell's energy charge is reduced, followed by RNA/DNA synthesis and then by ion regulation. In the cells of L. larseni, protein synthesis may be decreased upon cooling due to increased energy demand by other, unidentified processes. This conclusion is supported by a rise in oligomycin sensitive respiration (i.e. ATP synthesis rate) and an overall increase in cellular respiration at 0 and $3^{\circ} \mathrm{C}$. Judging from the stable cellular energetic conditions observed by NMR spectroscopy in live specimens of $P$. brachycephalum by Mark et al. (2002) during warming, there is most likely no drop in energy charge in the cells of all species used in this study, especially as the isolated cells are not constrained by systemic limitations.

In the high-Antarctic notothenioids, cellular energy budgets displayed characteristics different from L. larseni: in T. eulepidotus hepatocytes (Fig. 1b), we found a significant decrease in cycloheximide-sensitive respiration with rising temperature, possibly indicating the onset of a cellular metabolic capacity limitation. This limitation may lead to the predominant use of cellular ATP supply by baseline cellular functions, i.e. ion exchange, reflected in maintained fractions of ouabain dependent respiration. In the other species, no significant changes in cellular energy metabolism could be observed. It is astounding to find so few signs for a shift in ATP-consuming processes in the cells, even though they have been warmed to temperatures far beyond the survival range of the whole organisms (Somero and DeVries 1967). Thus, although showing signs of energetic optima at rather low temperatures, the restrictive 
mechanisms limiting whole organism thermal tolerance cannot be operative at the cellular level in these Antarctic notothenioids.

For a further evaluation of adaptation to different temperature regimes, an additional analysis was carried out for the nototheniids. Comparing total cycloheximide and ouabain sensitive respiration in the range from $0^{\circ} \mathrm{C}$ to $15^{\circ} \mathrm{C}$ (Fig. 3), cycloheximide sensitive respiration was found to be significantly higher in most of the highAntarctic nototheniids than in the sub-Antarctic species, while ouabain sensitive respiration displayed a contrasting trend and was somewhat lower. In the context with earlier observations by other authors, the observed bias in energy allocation may indicate that the stenothermal high Antarctic nototheniids possess greater protein synthesis capacities than the more eurythermal species but lower capacities of active ion regulation: Storch et al. (2005) observed higher protein synthesis capacities in the cold-eurythermal Antarctic eelpout $P$. brachycephalum as compared to the warm-eurythermal common eelpout Zoarces viviparus, and other authors also found evidence for cold compensated protein synthesis in high-Antarctic fish (Smith and Haschemeyer 1980) and sea urchin embryos (Marsh et al. 2001). Furthermore, several studies investigating $\mathrm{pH}$ and ion regulation in eurythermal and stenothermal fish (Pörtner and Sartoris 1999; Bock et al. 2001; Sartoris et al. 2003a) found the greater part of $\mathrm{pH}$ regulation in eurythermal fish to be dependent on active processes like regulation via $\mathrm{Na}^{+} / \mathrm{K}^{+}$-ATPase, while in stenothermal fish, less costly passive processes prevailed. Our data for protein synthesis rates in the sub-Antarctic nototheniid L. larseni on the one hand, and for $\mathrm{Na}^{+} / \mathrm{K}^{+}$-ATPase rates on the other hand, are consistent with these findings for eurythermal fish and can mark this species down as a more eurythermal species in comparison to the stenothermal high-Antarctic species.

\section{Conclusions}

Provided with sufficient energy and oxygen, cells can survive and maintain metabolic functions within a far wider thermal window than the more complex organisms from which they originate (cf. Somero and DeVries 1967). Apart from small changes in energy allocation in cycloheximide and oligomycin sensitive respiration in the sub-Antarctic notothenioid species L. larseni, there were no distinct shifts in energy allocation over the investigated thermal range, nor did we identify any threshold temperatures beyond which abrupt changes in energy budget occurred. Energetic limitations to thermal tolerance must therefore be set at the organismic level. Here they occur through a mismatch in oxygen supply and demand, provoking a progressive reduction in aerobic scope (Pörtner et al. 2004). Accordingly, our present findings indirectly support the concept of oxygen limited thermal tolerance (Pörtner 2001, 2002). In an earlier study in the Antarctic eelpout $P$. brachycephalum (Mark et al. 2002), we found evidence for a limitation in functional capacity of the cardio-vascular system, which has subsequently also been observed in cod (Sartoris et al. 2003b; Lannig et al. 2004) and rainbow trout (Farrell and Clutterham 2003), in line with earlier findings by Heath and Hughes (1973). The cod studies by Lannig, Sartoris and coworkers revealed the primary limiting role of the cardio-vascular system: Over a wide thermal range arterial oxygen partial pressure remained constant, while venous oxygen partial pressure decreased steadily from a maximum at the animals' optimal temperature towards both the cold and warm ends of the thermal range. Under progressively increasing thermal stress, cardio-vascular capacities are not sufficient to provide full aerobic scope and tissue oxygen extraction leaves venous blood increasingly oxygen depleted,
Fig. 3 Mean cycloheximide and ouabain sensitive cellular respiration as measured between $0^{\circ} \mathrm{C}$ and $15^{\circ} \mathrm{C}$ in the nototheniid species. Asteriks indicate cellular respiration values in the high-Antarctic nototheniids significantly different from the sub-Antarctic L. larseni $(P<0.05)$, all values given as means \pm standard error of the mean (SEM)

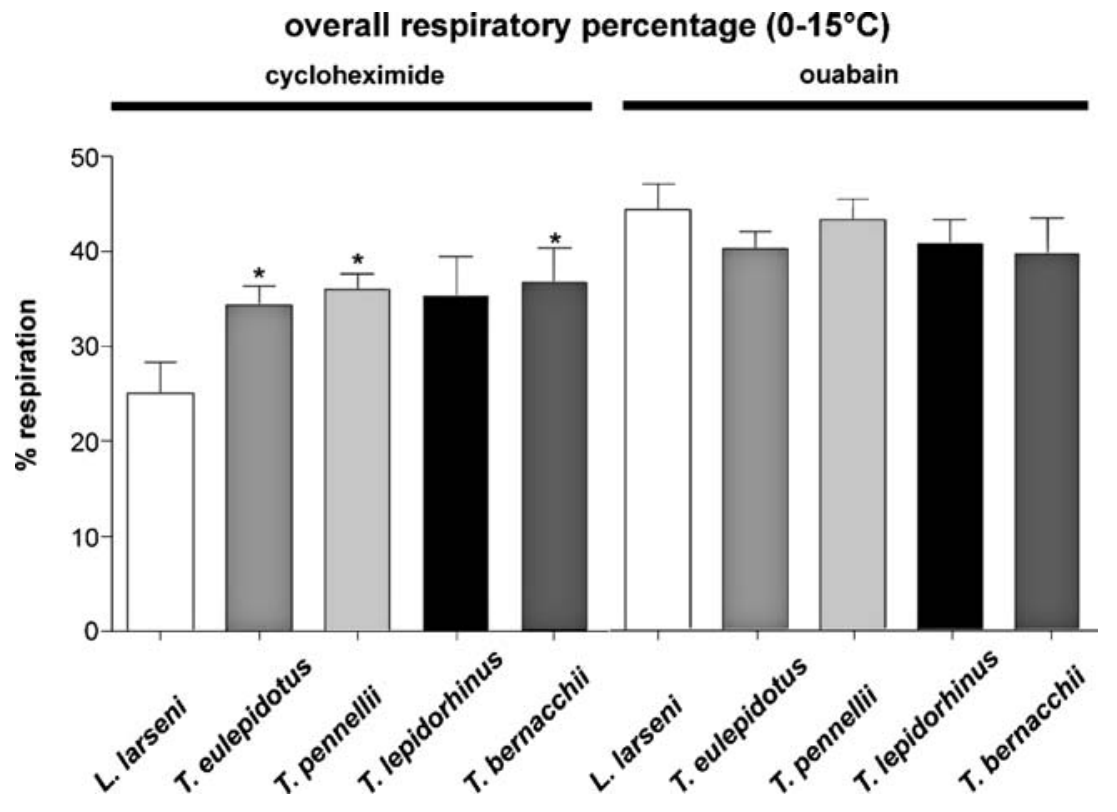


eventually culminating in cellular oxygen limitation. Moreover, many fish species lack coronary circulation and rely on the venous oxygen reserve for myocardial oxygen supply (Farrell 1993), thus only exacerbating the dilemma.

These considerations are consistent with the concept of a hierarchy of systemic to molecular processes contributing to thermal limitation in a complex organism (cf. Pörtner 2002; Pörtner et al. 2004). The most sensitive process with respect to thermal tolerance is supposed to be set at the highest levels of organisational complexity. In fish, cardio-vascular more than ventilatory performance appears to be the bottleneck of thermal tolerance, although the various levels of organisation have evolved into a complex organism, in which the capacities of systemic to molecular processes closely match. Taylor and Weibel (1981) developed the concept of symmorphosis, which states that the functional capacities of individual components are designed to suit the higher unit, i.e. the organism. Furthermore, the hypothesis indicates that an organism's functional capacities are never expressed in excess of its direct environmental needs. At the cellular level, the present data indicate a wider thermal window since the constraints at the higher levels of organisational complexity are no longer operative. The optimum of maximum cellular energy efficiency is still set to within the thermal range of the whole organism. Once organismic oxygen supply to cells by the cardio-vascular system declines, cellular hierarchies of energy allocation may become effective and lead to reductions in the scopes for growth and reproduction, then in cellular maintenance metabolism (DNA synthesis and ion homeostasis) and ultimately to cell death.

Acknowledgements The authors would like to thank E-M. Brodte, K. Mintenbeck, N. Koschnick, C. Bock, R. Knust and the crew of RV Polarstern cruise ANT XXI-2 for their valuable and excellent help in catch, identification, maintenance and preparation of the fish species used in this study, and T. Brey for his helpful comments on the statistics.

\section{References}

Arntz WE, Brey T, Gallardo VA (1994) Antarctic zoobenthos. Oceanogr Mar Biol Ann Rev 32:241-304

Atkinson D (1977) Cellular energy metabolism and its regulation. Academic, New York, pp 218

Bock C, Sartoris FJ, Wittig RM, Pörtner HO (2001) Temperaturedependent $\mathrm{pH}$ regulation in stenothermal Antarctic and eurythermal temperate eelpout (Zoarcidae): an in-vivo NMR study. Polar Biol 24:869-874

Bradford MM (1976) A rapid and sensitive method for the quantitation of microgram quantities of protein utilizing the principle of protein-dye binding. Anal Biochem 72:248-254

Buttgereit F, Brand MD (1995) A hierarchy of ATP-consuming processes in mammalian cells. Biochem J 312:163-167

Casey TM, Pakay JL, Guppy M, Arthur PG (2002) Hypoxia causes downregulation of protein and RNA synthesis in noncontracting Mammalian cardiomyocytes. Circ Res 90:777-783

Clarke A and Johnston NM (1999) Scaling of metabolic rate with body mass and temperature in teleost fish. J Anim Ecol 68:893905
D'Amico S, Claverie P, Collins T, Georlette D, Gratia E, Hoyoux A, Meuwis MA, Feller G, Gerday C (2002) Molecular basis of cold adaptation. Philos Trans R Soc Lond B Biol Sci 357:917925

Detrich HW III (1997) Microtubule assembly in cold-adapted organisms: functional properties and structural adaptations of tubulins from antarctic fishes. Comp Biochem Physiol A Physiol 118:501-513

Di prisco G (2000) Life style and biochemical adaptation in antarctic Fishes. J Mar Syst 27:253-265

Eastman JT (1993) Antarctic fish biology: evolution in a unique environment. Academic, New York

Egginton S (1997a) Control of tissue blood flow at very low temperatures. J Therm Biol 22:403-407

Egginton S (1997b) A comparison of the response to induced exercise in red- and white-blooded Antarctic fishes. J Comp Physiol B 167:129-134

Farrell AP (1993) Cardiac output in fish: regulation and limitations. In: Bicudo JE (eds) The vertebrate gas transport cascade: adaptions to environmet and mode of life. CRC Press Inc. Boca Raton, pp 208-214

Farrell AP, Clutterham SM (2003) On-line venous oxygen tensions in rainbow trout during graded exercise at two acclimation temperatures. J Exp Biol 206:487

Gamper NL, Savina MV (2000) Reversible metabolic depression in hepatocytes of lamprey (Lampetra fluviatilis) during prespawning: regulation by substrate availability. Comp Biochem Physiol B 127:147-154

Gon O and Heemstra P (1990) Fishes of the Southern Ocean. J.L.B. Smith Institute for Ichthyology, Grahamstown, South Africa

Hardewig I, Peck LS, Pörtner HO (1999) Thermal sensitivity of mitochondrial function in the Antarctic Notothenioid Lepidonotothen Nudifrons. J Comp Physiol B 169:597-604

Haschemeyer AEV and Mathews RW (1982) Effects of temperature extremes on protein synthesis in liver of toadfish, Opsanus tau, in vivo. Biol Bull Mar Biol Lab, Woods Hole 162:18-27

Heath AG and Hughes GM (1973) Cardiovascular and respiratory changes during heat stress in rainbow trout (Salmo gairdneri). J Exp Biol 59:323-38

Johnston IA, Calvo J, Guderley H, Fernandez D, Palmer L (1998) Latitudinal variation in the abundance and oxidative capacities of muscle Mitochondria in Perciform fishes. J Exp Biol 201:112

Kock KH (1992) Antarctic fish and fisheries. Cambridge University Press, Cambridge, UK

Krumschnabel G, Malle S, Schwarzbaum PJ, Wieser W (1994a) Glycolytic function in goldfish hepatocytes at different temperatures-relevance for $\mathrm{Na}+$ pump activity and protein-synthesis. J Exp Biol 192:285-290

Krumschnabel G, Schwarzbaum PJ, Wieser W (1994b) Coupling of energy supply and energy demand in isolated goldfish Hepatocytes. Physiol Zool 67:438-448

Krumschnabel G, Biasi C, Schwarzbaum PJ, Wieser W (1997) Acute and chronic effects of temperature, and of nutritional state, on ion homeostasis and energy metabolism in teleost hepatocytes. J Comp Physiol B 167:280-286

Krumschnabel G, Manzl C, Schwarzbaum PJ (2001) Importance of glycolysis for the energetics of anoxia-tolerant and anoxiaintolerant teleost hepatocytes. Physiol Biochem Zool 74:413419

Langenbuch M and Pörtner HO (2003) Energy budget of hepatocytes from Antarctic fish (Pachycara brachycephalum and Lepidonotothen kempi) as a function of ambient $\mathrm{CO}_{2}: \mathrm{pH}-$ dependent limitations of cellular protein biosynthesis? J Exp Biol 206:3895-3903

Lannig G, Bock C, Sartoris FJ, Pörtner HO (2004) Oxygen limitation of thermal tolerance in cod, Gadus morhua L., studied by magnetic resonance imaging and on-line venous oxygen monitoring. Am J Physiol Regul Integr Comp Physiol 287:R902R910 
Lucassen M, Schmidt A, Eckerle LG, Pörtner HO (2003) Mitochondrial proliferation in the permanent vs. temporary cold: enzyme activities and mRNA levels in Antarctic and temperate zoarcid fish. Am J Physiol Regul Integr Comp Physiol 285:R1410-R1420

Mark FC, Bock C, Pörtner HO (2002) Oxygen-limited thermal tolerance in Antarctic fish investigated by MRI and 31P-MRS. Am J Physiol 283:R1254-R1262

Marsh AG, Maxson REJ, Manahan DT (2001) High macromolecular synthesis with low metabolic cost in Antarctic sea urchin embryos. Science 291:1950-1952

Mommsen TP, Moon TW, Walsh PJ (1994) Hepatocytes: isolation, maintenance and utilization. In: Hochachka PW, Mommsen TP (eds) Biochemistry and molecular biology of fishes, analytical techniques, vol. 3. chapter 30, Elsevier Science, Amsterdam, pp 355-372

Pannevis MC, Houlihan DF (1992) The energetic cost of proteinsynthesis in isolated hepatocytes of rainbow-trout (Oncorhynchus-Mykiss). J Comp Physiol B 162:393-400

Pörtner HO and Sartoris FJ (1999) Invasive studies of intracellular acid-base parameters: quantitative analyses during environmental and functional stress. In: Taylor EW, Egginton S, Raven JA (eds) Regulation of tissue $\mathrm{pH}$ in plants and animals: a reappraisal of current techniques. SEB Seminar Series. Cambridge University Press, Cambridge England, pp 69-98

Pörtner HO (2001) Climate change and temperature-dependent biogeography: oxygen limitation of thermal tolerance in animals. Naturwissenschaften 88:137-146

Pörtner HO (2002) Climate variations and the physiological basis of temperature dependent biogeography: systemic to molecular hierarchy of thermal tolerance in animals. Comp Biochem Physiol A Mol Integr Physiol 132:739-761

Pörtner HO, Mark FC, Bock C (2004) Oxygen limited thermal tolerance in fish? Answers obtained by nuclear magnetic resonance techniques. Respir Physiol Neurobiol 141:243-260
Pörtner HO, Lucassen M, Storch D (2005) Metabolic biochemistry, thermal tolerance and the capacities of physiological and ecological function: an integrative view. Fish Physiol, 22 in press

Sartoris FJ, Bock C, Pörtner HO (2003a) Temperature-dependent $\mathrm{pH}$ regulation in eurythermal and stenothermal marine fish: an interspecies comparison using 31P-NMR. J Therm Biol 28:363371

Sartoris FJ, Bock C, Serendero I, Lannig G, Pörtner HO (2003b) Temperature dependent changes in energy metabolism, intracellular $\mathrm{pH}$ and blood oxygen tension in the Atlantic cod. J Fish Biol 62:1239-1253

Smith MAK and Haschemeyer AEV (1980) Protein metabolism and cold adaptation in Antarctic fishes. Physiol Zool 53:373-382

Smith RW, Houlihan DF (1995) Protein-synthesis and oxygenconsumption in fish cells. J Comp Physiol B 165:93-101

Smith RW, Blaney SC, Dowling K, Sturm A, Jonsson M, Houlihan DF (2001) Protein synthesis costs could account for the tissuespecific effects of sub-lethal copper on protein synthesis in rainbow trout (Oncorhynchus Mykiss). Aquat Toxicol 53:265-277

Somero GN, DeVries AL (1967) Temperature tolerance of some Antarctic fishes. Science 156:257-258

Storch D, Lannig G, Pörtner H (2005) Temperature dependent protein synthesis capacities in Antarctic and temperate (North Sea) fish (Zoarcidae). J Exp Biol 208:2409-2420

Taylor CR and Weibel ER (1981) Design of the mammalian respiratory system. I: problem and strategy. Respir Physiol 44:1-10

Van Dijk PLM, Hardewig I, Tesch C, Pörtner HO (1999) Physiological disturbances at critically high temperatures: a comparison between stenothermal Antarctic, and eurythermal temperate eelpouts (Zoarcidae). J Exp Biol 202:3611-3621

Wieser W and Krumschnabel G (2001) Hierarchies of ATP-consuming processes: direct compared to indirect measurements, and comparative aspects. Biochem J 355:389-395 